\title{
Onset of deep drainage and salt mobilization following forest clearing and cultivation in the Chaco plains (Argentina)
}

\author{
M. L. Amdan, ${ }^{1}$ R. Aragón, ${ }^{2,3}$ E. G. Jobbágy, ${ }^{3}$ J. N. Volante, ${ }^{4}$ and J. M. Paruelo ${ }^{1,5}$ \\ Received 19 April 2013; revised 23 August 2013; accepted 3 September 2013; published 15 October 2013.
}

[1] Semiarid sedimentary plains occupied by dry forest ecosystems often display low groundwater recharge rates and accumulation of salts in the soil profile. The transformation of these natural systems to rain-fed agriculture has led to raising water tables and a slow, but steady, process of groundwater and soil salinization in vast areas of Australia. In the semiarid plains of Chaco (central South America), unprecedented deforestation rates are taken place. Based on deep soil sampling $(0-6 \mathrm{~m})$ in seven paired stands under natural dry forest, rain-fed agriculture and pasture, with different age of clearance ( $>30$ years, 20 and 3 years) in Salta, Argentina, we provide evidence of groundwater recharge increase and onset of salt mobilization in areas where forests were replaced by annual croplands. Soils with higher water and lower chloride content are evidence of deep percolation and salt leaching. In Salta, stands subject to 30 years of rain-fed cultivation had profiles with $30-46 \%$ higher moisture content and 94\% lower chloride stocks compared to dry forest $\left(0.05 \pm 0.04 \mathrm{~kg} / \mathrm{m}^{2}\right.$ versus $0.77 \pm 0.4 \mathrm{~kg} / \mathrm{m}^{2}$ ). Estimates of groundwater recharge based on the displacement of chloride peaks suggested values of $27-87 \mathrm{~mm} \mathrm{yr}^{-1}$ for agricultural soybean stands, and $10.4 \mathrm{~mm} \mathrm{yr}^{-1}$ for pastures. While hydrological shifts in the regional groundwater system are poorly monitored and understood, our findings show that it is potentially sensitive to land use changes and to salinization processes.

Citation: Amdan, M. L., R. Aragón, E. G. Jobbágy, J. N. Volante, and J. M. Paruelo (2013), Onset of deep drainage and salt mobilization following forest clearing and cultivation in the Chaco plains (Argentina), Water Resour. Res., 49, 6601-6612, doi:10.1002/wrcr.20516.

\section{Introduction}

[2] Economic globalization along with the growing demand for soybean products has been a major driver of industrial agriculture expansion in subtropical and temperate areas [Grau et al., 2008; Paruelo et al., 2011]. Dry forests and savannas of tropical and subtropical South America experience one of the largest rates of transformation [Grau et al., 2008; Volante et al., 2011]. The Chaco plains region has been particularly affected with average deforestation rates surpassing those at the continental and

Additional supporting information may be found in the online version of this article.

${ }^{1}$ Facultad de Agronomía, Departamento de Métodos Cuantitativos y Sistemas de Información, University of Buenos Aires, Buenos Aires, Argentina.

${ }^{2}$ Instituto de Ecologia Regional (IER), Facultad de Ciencias Naturales e Instituto Miguel Lillo, University of Tucumán, Tucumán, Argentina.

${ }^{3}$ Grupo de Estudios Ambientales, IMASL, Universidad Nacional de San Luis and CONICET, San Luis, Argentina.

${ }^{4}$ Laboratorio de Teledetección y SIG, INTA Salta, Salta, Argentina.

${ }^{5}$ Laboratorio de Análisis Regional y Teledetección and IFEVA, University of Buenos Aires and CONICET, Buenos Aires, Argentina.

Corresponding author: M. L. Amdan, Facultad de Agronomía, Departamento de Métodos Cuantitativos y Sistemas de Información, University of Buenos Aires, Av. San Martín 4453, C1417DSE Buenos Aires, Argentina. (lauraamdan@gmail.com)

C2013. American Geophysical Union. All Rights Reserved. 0043-1397/13/10.1002/wrcr.20516 global level $(0.82 \%$ per year in Argentina, $0.51 \%$ for South America, and $0.2 \%$ globally [Food and Agriculture Organization of the United Nations (FAO), 2009; Unidad de Manejo del Sistema de Evaluación Forestal (UMSEF), 2007]). Such loss is typically concentrated in highly active foci like those in the provinces of Santiago del Estero, Salta, and Chaco [Paruelo et al., 2011].

[3] A critical issue in the analysis of the effects of land cover transformations is to anticipate those consequences that due to lags in their onset and/or perception by people may be ignored when land use decisions are taken. Water balance and hydrological regulation shifts, particularly in flat semiarid landscapes like Chaco plains, may be an example of this type of land use change consequences, with likely temporal and spatial decoupling between actions and effects. Many areas of the world experienced profound changes in groundwater dynamics due to changes in land cover by altering the timing and magnitude of evapotranspiration [Scanlon et al., 2006]. Most of these changes were not evaluated until losses services such as the regulation of streamflows, water table levels, and salt storage/transport processes were impaired. In the Chaco plains of South America the processes of land transformation accelerated less than a decade ago and the risks of profound changes in groundwater recharge and soil salinization are not considered by decision makers as there are not immediate and visible effects over agriculture yields. Here we analyze changes in the Chaco plains water dynamics that may result in increasing water table level and salinization processes. 
[4] The water balance of a given plot results from the difference between inputs (precipitation and run on) and the outputs (deep drainage, runoff, and evapotranspiration). Dry forests on sedimentary plains often make an exhaustive evapotranspirative use of precipitation inputs generating nil deep drainage and low surface runoff at the landscape level [Jobbágy et al., 2008]. In these systems solutes incorporated through rain and dry deposition [Scanlon et al., 2005a] and rock weathering accumulate over time in the soil profile approaching in some cases several tons per square meter [Cook et al., 1989]. After the establishment of crops the "zero recharge" condition of forests is often interrupted. The reduced crop evapotranspiration determined that a portion of water entering the system drain beyond the area explored by the roots and into the groundwater (deep drainage). Increasing soil water content and circulation leads to salt leaching and transport to greater depth and eventually the groundwater system. Shallower root systems and fallow periods aimed to store soil water for the next growing season are some of the key differences between croplands and native forests, which lead to these changes [Jobbágy et al., 2008]. In very flat sedimentary landscapes these contrasts produce gradual water level raises with cultivation that can mobilize salts vertically and horizontally affecting soil and water resources [George et al., 1997; Schofield et al., 2001; Jobbágy and Jackson, 2004; Nosetto et al., 2007; Jobbágy et al., 2008].

[5] The redistribution of salts and the rise of groundwater levels has been described in southwestern Australia [George et al., 1997], in semiarid plains of the Sahel [Leduc et al., 2001; Leblanc et al., 2008] in the southwestern Great Plains of North America [Scanlon et al., 2005b] and recently in the Espinal forests of Argentina [Santoni et al., 2010; Jayawickreme et al., 2011]. These systems showed slow but continuous increases of water table levels and groundwater salinization and in the case of Australia they affected the surface impairing more than $10 \%$ of its agricultural land [National Land and Water Resources Audit (NLWRA), 2001]. The Chaco plains are potentially vulnerable to this type of salinization processes, given their semiarid to subhumid climate, natural dominance of woody vegetation, and very flat sedimentary terrain [Paruelo et al., 2001; Volante et al., 2011]. Yet whether these plains sustain a "zero recharge" condition and high salt accumulation under natural vegetation is poorly known, except for a few local studies [Nitsch, 1995; Nitsch et al., 1998; Contreras et al., 2012].

[6] The study of groundwater recharge in arid and semiarid areas is often based on indirect methods involving environmental tracers such as chloride and tritium [Ruiz, 2003]. While there are several uncertainties associated with the estimate of tracer input sand transport, they are generally less important than the logistic problems associated with alternative and more direct approaches focused on the water balance components [Scanlon et al., 2002]. Recharge rates can be assessed by measuring chloride concentrations throughout the soil and sediment profile and their shifts with land use explored by comparing sites with similar substrate and deposition that have hosted different land covers. Atmospheric chloride inputs can work as a useful tracer of deep recharge given the solubility and mobility of this ion in the soil, its widespread scarcity in rocks (making weath- ering contributions small), and its relatively poor consumption and recycling by plants when its soil stock is large (making biological uplift small) [Pavelic et al., 1997; Jobbágy and Jackson, 2003; Ruiz, 2003; Nolan et al., 2007; Santoni et al., 2010]. Dry profiles with chloride accumulation indicate null or minimal recharge, while wet and lower chloride concentration soils are evidence of deep percolation and salt leaching [Phillips, 1994].

[7] The aim of this study was to evaluate the effect of forest clearing and cultivation on deep drainage and salt mobilization and explore the risks of water table raise and soil salinization in the Chaco plains of South America (Argentina). For this purpose, we used a set of seven paired stands that included native dry forests and cultivated plots that were cleared at different times. In each stand we characterized moisture content, chloride, electrical conductivity, among other variables, down to $6 \mathrm{~m}$ of depth. Based on this information, we estimated recharge rates with two indirect methods: residual moisture flux (RMF) [Phillips, 1994] and chloride front displacement (CFD) [Walker et al., 1991].

\section{Materials and Methods}

\subsection{Study Region}

[8] We focused our study in the Gran Chaco, particularly in the northwest of Argentina in the province of Salta (Figure 1) which is entirely hosted by the Semiarid Chaco ecoregion [Cabrera, 1976]. Climate is semiarid, with the monthly rate of evapotranspiration (ET) higher than precipitation during the whole year [Bianchi et al., 2005]. Mean monthly temperatures go from $28^{\circ} \mathrm{C}$ in summer to $14^{\circ} \mathrm{C}$ in winter and with frost period that goes from May to September [Del Castillo, 1985]. Semiarid Chaco has a summer rainy season (November-March) and a dry winter [Bianchi et al., 2005]. For each sampled site, we characterized mean annual precipitation from TRMM images (Tropical Rainfall Measurement Mission 3B42 product) from 1998 to 2010 [Aragón et al., 2010]. We considered this product the best option for rainfall data because meteorological stations had incomplete data, or few recorded years or are at considerable distance from the study sites. Mean annual precipitation for each site varied from 844 to $899 \mathrm{~mm}$ per year (Table 1).

[9] Natural rangeland vegetation is characterized by a xerophytic and semideciduous forest dominated by quebracho Colorado santiagueño (Schinopsislorentzzi), quebracho blanco (Aspidospermaquebracho-blanco), palo santo (Bulnesiasarmientoi), and ibirá-morotí (Calycophyllummultiflorum). Other common species are mistol (Ziziphusmistol), itín (Prosopiskuntzei), palocruz (Tabebuianodosa), guayacán (Libidibiaparaguariensis), and carandilla (Trithinaxbiflabellata) [Tortorelli, 2009; Brown et al., 2006].

[10] The slope of the study area is about $0.1 \%$ [GE, http://www.earth.google.com] interrupted by the presence of the paleochannels [Iriondo, 1993; Instituto Nacional de Tecnología Agropecuaria (INTA), 2009a]. Geomorphologically, is hosted by the occidental side of the "Llanura Chaqueña," in the Salado-Juramento basin [Sayago, 1995]. This is a large sedimentary basin with an irregular and discontinuous array of loessic sediments over fine alluvial deposits (Salado alluvial fan deposition system) [Iriondo, 


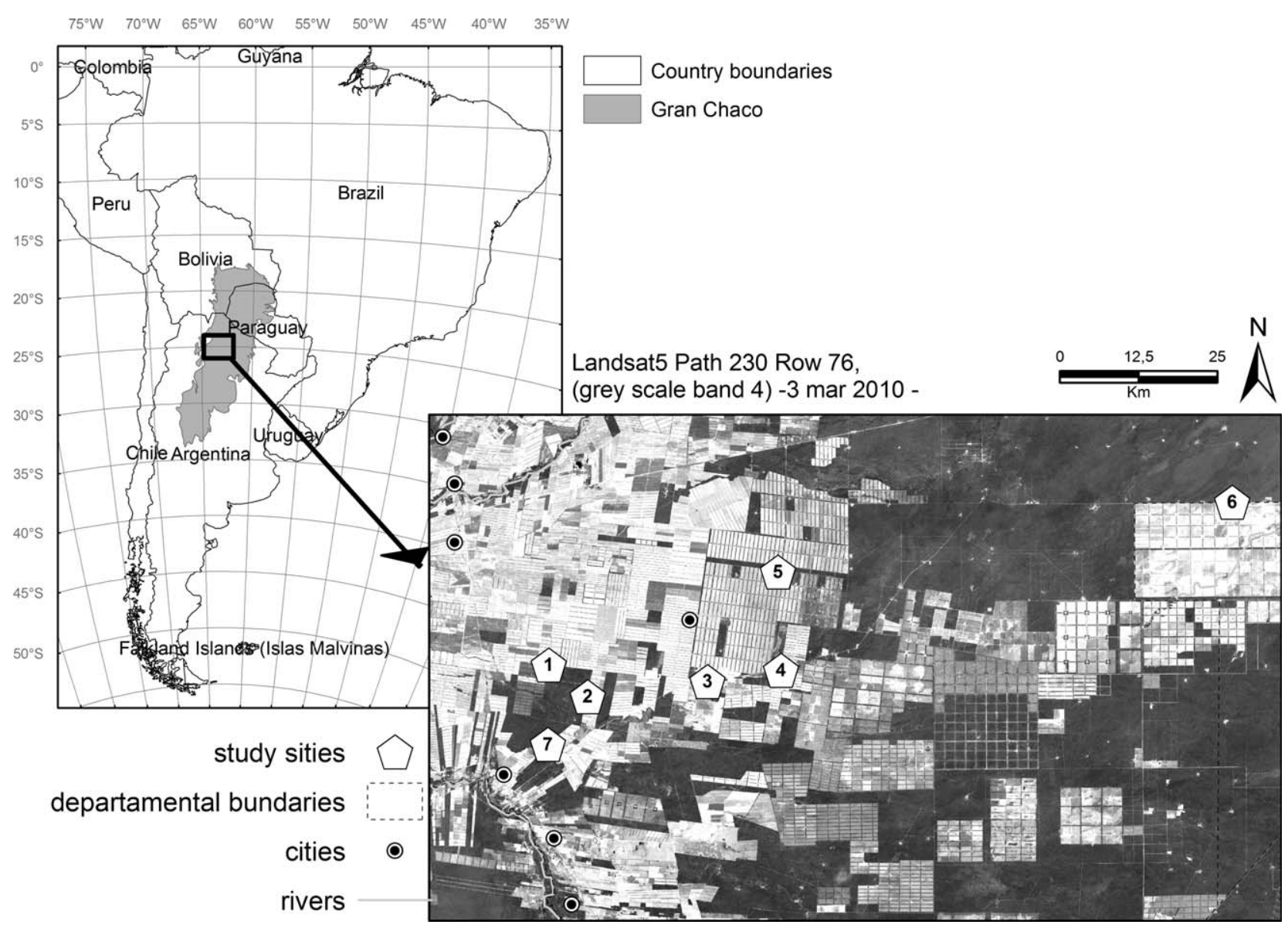

Figure 1. Study region and sampled sites. Each number identifies a dry forest-agricultural stand pair (or triplet in the case of site 7).

1993]. The study area has multilayer groundwater system with an unconfined aquifer and an undetermined number of confined to semiconfined aquifers which underlie the first one, located at variable depths between 12 and $20 \mathrm{~m}$ [Garcia, 1998; Vargas, 1997]. Deep recharge is considered to be mostly remote with the main contributor being mountain-front infiltration in the west of the region [Garcia, 1998; Fuertes, 2004].

\subsection{Study Sites}

[11] We selected seven sites with paired neighboring stands occupied by rain-fed (nonirrigated) agriculture and dry forest (DF) in the east of Salta province (Table 1 and Figure 1). The history of these sites represents NW Argentina agriculture, which is predominantly based on no-tillage management and seasonal fallow periods [Instituto Nacional de Tecnología Agropecuaria (INTA), 2005]. In each site we sampled two stands with exception of site 7 , in which an additional stand occupied by irrigated agriculture was added. Cadastral and clearance years were obtained from an existing database [Volante et al., 2009] and from LANDSAT 5 TM images (from 1976 to 2009, Path 230, Row 76). The counties covered by the study currently concentrate $61 \%$ of the total area deforested between 2001 and 2007 in the whole province, and are dominated by rain-fed crops [INTA, 2009a]. A first set of agricultural stands, cor- responding to sites 1-4, was cleared between 1978 and 1980 and was considered "old agriculture" (OA). An additional agricultural stand located in site 5 was cleared in 2007 and it was considered "new agriculture" (NA). At site 6 we also sampled a perennial pasture that was established after clearing the forest in 1990, this stand was considered "old pasture" (OP). The boreholes were placed 50$75 \mathrm{~m}$ away from the edge of the plots, making distances between paired boreholes range between 100 and $150 \mathrm{~m}$. The same topographic position was sampled in each stand, with microdepressions, slopes, roads, or borders with other land coverage avoided in all cases.

[12] Soils correspond to Argiudols and Haplustols [United States Department of Agriculture (USDA), 1992]. Soil subgroups included aridic and udic Argiudols, depending on the slight climatic differences, and less developed entic Haplustols. These are all well-drained and nonsodic soils. For site 6 , soil corresponds to the vertic Haplustalfs subgroup and has a slightly poorer drainage [Instituto Nacional de Tecnología Agropecuaria (INTA), 2009b].

\subsection{Measurements and Data Analysis}

[13] Soil samples were obtained during the austral spring of 2010, at the end of the dry season. Paired stands were always sampled within the same day. Bulk sediment samples were collected at intervals of $50 \mathrm{~cm}$, with a $10 \mathrm{~cm}$ diameter 
Table 1. Location and Environmental Data for the Study Sites ${ }^{\mathrm{a}}$

\begin{tabular}{|c|c|c|c|c|c|c|c|c|}
\hline \multirow[b]{2}{*}{ Site } & \multirow[b]{2}{*}{ Use } & \multirow[b]{2}{*}{ Clearance Year } & \multirow[b]{2}{*}{ Precipitation $(\mathrm{mm})$} & \multirow[b]{2}{*}{$\mathrm{Cl}^{-}$Deposition $\left(\mathrm{g} / \mathrm{m}^{2} \mathrm{yr}\right)$} & \multirow[b]{2}{*}{ Location } & \multicolumn{3}{|c|}{ Texture } \\
\hline & & & & & & Clay (\%) & Silt (\%) & Sand $(\%)$ \\
\hline \multirow[t]{2}{*}{1} & OA & $1978 / 1980$ & 899 & 0.4617 & $24^{\circ} 56^{\prime} 53^{\prime \prime} \mathrm{S}$ & 31 & 28 & 41 \\
\hline & DF & & & & $64^{\circ} 04^{\prime} 07^{\prime \prime} \mathrm{O}$ & 16 & 24 & 60 \\
\hline \multirow[t]{2}{*}{2} & OA & $1978 / 1980$ & 899 & 0.4617 & $24^{\circ} 59^{\prime} 36^{\prime \prime} \mathrm{S}$ & 18 & 23 & 59 \\
\hline & DF & & & & $64^{\circ} 00^{\prime} 47^{\prime \prime} \mathrm{O}$ & 24 & 17 & 60 \\
\hline \multirow[t]{2}{*}{3} & OA & $1978 / 1980$ & 866 & 0.4452 & $24^{\circ} 58^{\prime} 19^{\prime \prime} \mathrm{S}$ & 26 & 27 & 47 \\
\hline & DF & & & & $63^{\circ} 50^{\prime} 27^{\prime \prime} \mathrm{O}$ & 28 & 34 & 38 \\
\hline \multirow[t]{2}{*}{4} & $\mathrm{OA}$ & $1978 / 1980$ & 877 & 0.4507 & $24^{\circ} 57^{\prime} 20^{\prime \prime} \mathrm{S}$ & 24 & 28 & 48 \\
\hline & DF & & & & $63^{\circ} 44^{\prime} 14^{\prime \prime} \mathrm{O}$ & 30 & 39 & 30 \\
\hline \multirow[t]{2}{*}{5} & NA & 2007 & 877 & 0.4507 & $24^{\circ} 48^{\prime} 54^{\prime \prime} \mathrm{S}$ & 25 & 46 & 29 \\
\hline & DF & & & & $63^{\circ} 44^{\prime} 01^{\prime \prime} \mathrm{O}$ & 26 & 38 & 36 \\
\hline \multirow[t]{2}{*}{6} & OP & 1990 & 844 & 0.4342 & $24^{\circ} 43^{\prime} 03^{\prime \prime} \mathrm{S}$ & 11 & 15 & 74 \\
\hline & DF & & & & $63^{\circ} 05^{\prime} 56^{\prime \prime} \mathrm{O}$ & 17 & 18 & 66 \\
\hline \multirow[t]{3}{*}{7} & IA & $1978 / 1980$ & 884 & 0.4542 & $25^{\circ} 03^{\prime} 42^{\prime \prime} \mathrm{S}$ & 25 & 40 & 35 \\
\hline & OA & 1978/1980 & & & $64^{\circ} 04^{\prime} 12^{\prime \prime} \mathrm{O}$ & 27 & 38 & 36 \\
\hline & DF & & & & & 29 & 34 & 36 \\
\hline
\end{tabular}

\footnotetext{
${ }^{a}$ Mean annual precipitation was obtained from TRMM data for 1998-2009. Estimates of $\mathrm{Cl}^{-}$depositions were obtained in San Luis, Argentina and adjusted according to precipitation [Santoni et al., 2010]. Textural composition (\%) corresponds to average values obtained throughout all soil profiles sampled at each site. Land uses include old agriculture (OA) which rain-fed unless mentioned, old pastures (OP), new agriculture (NA), and dry forest (DF). All profiles are $6 \mathrm{~m}$ deep except for site $1 \mathrm{OA}(10 \mathrm{~m})$, and profiles at site 7 that were sampled down to the water table (IA $=2 \mathrm{~m}, \mathrm{OA}=3.5 \mathrm{~m}$, and $\mathrm{DF}=5 \mathrm{~m})$.
}

hand auger, reaching $6 \mathrm{~m}$ depth below the land surface, except for agricultural stand at site 1 where sampling was extended down to $10 \mathrm{~m}$ depth. We only reached the water table in the three stands at site 7 (see boreholes depths at Table 1). Full cores from each sampling interval were homogenized, sampled, and immediately sealed into double polyethylene bags. A total of 173 samples were collected. For measurements of gravimetric water content, samples and bags were weighted and the whole sample oven-dried at $105^{\circ} \mathrm{C}$ to reach constant weight. Polyethylene bags were airdried and weighted. Gravimetric water content $\left(\theta_{g}\right)$ was obtained as the initial sample weight including polyethylene bags minus the dry sample and dried bag weight.

[14] Soil texture was measured by the Bouyoucos method [Bouyoucos, 1962; Elliot et al., 1999]. Bulk density, field capacity, and the moisture content at saturation were obtained from existing pedotransfer functions [USDA, 1992; Rawls et al., 1992] based on texture.

[15] A relative water content value $\left(\theta_{r}\right)$ describing the departure from field capacity was obtained as:

$$
\theta_{r}=\theta_{v} / F C_{v}
$$

where $\theta_{r}$ is the relative water content $(\%), \theta_{v}$ is the volumetric water content measured $(\%)$, and $F C_{v}$ is the volumetric field capacity (\%) obtained from the table of USDA [1992]. The $\theta_{r}$ value allows us to compare moisture profiles with different water-holding capacity.

[16] Electric conductivity (EC), pH, and chloride content were measured in soil water extracts $(1: 2$, soil:water ratio). Two independent extracts from each sample were measured. Chloride concentration was measured with a solidstate ion-selective electrode [Frankenberger et al., 1996] and calibrated every six samples, using known chloride concentration extracts $(4.8 ; 9.16 ; 24 ; 100.8 ; 500$ ppm $\mathrm{Cl}^{-}$). The $\mathrm{pH}$ and EC were measured with Multiparametric analyzer CONSORT 0861, with pH electrode: S20-00B and for EC: Orion model 290A [Thomas, 1996]. The same methods and instrumental for $\mathrm{pH}, \mathrm{EC}$, and chloride meas- urements were used for groundwater samples from site 7 and for the Juramento river water sample.

[17] We analyzed data using repeated measures ANOVA with land cover (old agriculture and dry forest) as the main factor and depth intervals as the repeated factor (12 levels). A paired $t$ test was used to analyze differences in chloride, $\mathrm{pH}$, moisture, and EC between land covers. The results from new agriculture (NA), old pasture (OP) and stands from site 7 were only descriptive since we did not count with replicates to perform statistical analysis. In order to evaluate texture match (and soil similarity) between stands within sites, a proportional similarity index (PSI) [Feinsinger, 1981] was used for each site at $i$ depth:

$$
\text { PSI }=\sum \min \left(p_{1 i}, p_{2 i}, p_{3 i}\right)
$$

where $p_{1}$ to $p_{3}$ represent the lowest percentage value of both compared profiles for clay, silt, and sand, respectively, for a given depth $i$.

[18] Recharge was estimated based on chloride data using two methods; one based on the chloride mass balance (CMB) approach [Phillips, 1994] and the other based on the tracer front displacement (CFD) approach, being chloride the tracer used [Walker et al., 1991; Allison et al., 1994].

[19] CMB was used to estimate recharge at both dry forests and agricultural stands. This method assumes that (i) chloride transport is well approximated by a piston flow regime, (ii) all inputs to the ecosystem originate from atmospheric deposition, with rock weathering supply being negligible, (iii) plant uptake and storage in biomass and organic matter are negligible components of the chloride balance [Allison et al., 1985; Santoni et al., 2010], and (iv) chloride fluxes are in steady state [Walker et al., 1991; Allison et al., 1985]. This conservative behavior enables the calculation of the residual moisture flux [Phillips, 1994] as follows:

$$
R=\left(P \times \mathrm{Cl}_{p} / \mathrm{Cl}_{s w}\right)
$$

where $R$ is the net downward residual flux at the depth of measurement $\left(\mathrm{mm} \mathrm{yr}^{-1}\right), P$ is the mean annual precipitation 
$\left(\mathrm{mm} \mathrm{yr}^{-1}\right), \mathrm{Cl}_{p}$ is the chloride rain concentration $(\mathrm{mg} / \mathrm{L})$ $\left(\mathrm{Cl}^{-}\right.$deposition rate: $\mathrm{g} / \mathrm{m}^{2} \mathrm{yr}$, values at Table 1$)$, and $\mathrm{Cl}_{s w}$ is the measured $\mathrm{Cl}^{-}$concentration in the soil water $(\mathrm{mg} / \mathrm{L})$ (see section 2). Plotting cumulative $\mathrm{Cl}^{-}$content (mass $\mathrm{Cl}^{-}$ per unit volume of soil) with depth against cumulative water content measured (volume water per unit volume of soil) at the same depths we determined the value of $\mathrm{Cl}_{s w}$ [Santoni et al., 2010]. In all cases linear segments were found after the first 2 or $4 \mathrm{~m}$ depth. The slopes of these linear segments were considered as the $\mathrm{Cl}_{s w}$ value of equation (4) [Phillips, 1994]. The values of $P \times \mathrm{Cl}_{p}$ were obtained by modeling $\mathrm{Cl}^{-}$deposition data from Santoni et al. [2010] who made estimates for San Luis province, Argentina. Santoni et al. [2010] estimates for $\mathrm{Cl}^{-}$deposition were regressed with mean annual precipitation (map) data used for those estimates in San Luis. The regression equation obtained $\left(R^{2}=0.915 ; \mathrm{Cl}_{p}=0.00045\right.$ map +0.0122$)$ was used to estimate $\mathrm{Cl}^{-}$depositions in our study sites by substituting precipitations values with the corresponding values of mean annual precipitation obtained from TRMM images (3B42 product, 10 years average) (Table 1).

[20] The second approach, the CFD method, does not assume a steady state chloride flux but relies on the observation of shifts in the vertical profile of the tracer assuming that the chloride front moves in a vertical "piston-flow" mechanism [Walker et al., 1991]. This movement can be observed comparing chloride concentration curves between the dry forest (initial time) and the nearby agricultural stand (final time), resulting in an adequate method to evaluate consequences in salt storage derived from vegetation changes [Walker, 1998]. Recharge is determined from the displacement velocity $(v)$ of the chloride front:

$$
R=v \theta=\theta \times\left(Z_{1}-Z_{2}\right) /\left(t_{1}-t_{2}\right)
$$

where $R$ is the recharge $\left(\mathrm{mm} \mathrm{yr}^{-1}\right), \theta$ is the average water content over this depth interval, and $Z_{1}$ and $Z_{2}$ are the depth of the chloride peaks corresponding to times $t_{1} \times t_{2}$, being $t_{1}$ the age of clearance of the agricultural stand (see Table 1 ) and $t_{2}$ the age of clearance of the dry forest ( 0 years). Value of $6 \mathrm{~m}$ depth was used for $Z_{1}$ when no chloride peak was present (yielding minimum estimate) [Scanlon et al., 2005 b]. With $R$ values obtained from the CFD method, we estimated for agricultural stands, the time until the whole profile reach the saturation point assuming no lateral groundwater flow [Walker, 1998]. In other words, the time remaining until water table rises to surface. Assumed scenarios included (i) two possible settings with initial water table depth of 12 and $20 \mathrm{~m}$ [Vargas, 1977], (ii) below $6 \mathrm{~m}$ depth (explored depth) soil moisture content was equal to field capacity (FC), (iii) saturation point (SP) and FC were calculated based on the textural class of each sample and the table developed by USDA [1992] [Rawls et al., 1992], (iv) texture of the deepest measured sample $(6$ or $10 \mathrm{~m}$ depth) was considered as the texture throughout the rest of the profile, and (v) $R$ value remains constant over time. Rising time was calculated as:

$$
\begin{aligned}
& T_{1(0-6 \mathrm{~m})}=\left(\theta_{S P}-\theta_{A}\right) / R \\
& T_{2(6-i \mathrm{~m})}=\left(\theta_{S P}-\theta_{F C}\right) / R
\end{aligned}
$$

$$
T_{t}=T_{1}+T_{2}
$$

where $T_{1}$ (years) is time until moisture content reaches SP in the first $6 \mathrm{~m}$ of the profile, $\theta_{S P}(\mathrm{~mm})$ is the water sheet estimated for that profile at the saturation point, $\theta_{A}(\mathrm{~mm})$ is the current water sheet (measured water content), $R$ is the recharge value $\left(\mathrm{mm} \mathrm{yr}^{-1}\right) . T_{2}$ is time until moisture content between 6 and $12 \mathrm{~m}$ water table reaches SP (repeated for $20 \mathrm{~m}$ water table depth) and $\theta_{F C}$ is the water sheet estimated for that profile at field capacity. Finally, the time $\left(T_{t}\right)$ until water table reached the first meters of the soil profile, was calculated as the sum of $T_{1}$ and $T_{2}$.

\section{Results}

\subsection{Texture}

[21] Paired stands within each site had similar soil textures suggesting that our use of spatial differences to infer temporal changes was appropriate (Table 1). Only 20\% of the paired samples (agriculture versus dry forest at the same site and depth) had a proportional similarity index (PSI) value $<0.8$ and only $1 \%$ has PSI $<0.5$. Values between stands within a site were always higher than those obtained comparing sites (supporting information Figure S1).

\subsection{Moisture}

[22] Moisture contents $\left(\theta_{v}\right)$ were higher for both new and old agricultural stands when compared to dry forests (Figure 2). Water storage (0-6 m of depth) under old agriculture (OA) was significantly higher than under dry forest (DF), with differences ranging between +22 and $+59 \%$ $\left(t_{g l: 3}=3.18, p=0.028\right)$ (Table 2$)$. Water gains were intermediate $(+16 \%)$ under the new agricultural field (NA) and very modest $(+1.6 \%)$ under the old pasture (OP) (Table 2$)$.

[23] Relative water content $\left(\theta_{r}\right)$, defined as the ratio between observed and field capacity volumetric moisture values was higher under OA than DF ( 0.8 versus 0.5 on average respectively, maximum $=1$, Figure 3 ), averaging $29.5-46.3 \%$ higher values for OA than for their paired DF (ANOVA; $F_{1,66}$ for land cover $=27.6 ; p=0$. 0019). OP and NA sites showed a similar trend but with smaller differences with DF ( 0.7 and 0.6 on average, respectively, Figure 3 ). We found a linear increase of relative water content with time since clearing and cultivation, suggesting that at the speed at which profiles are approaching field capacity $\left(0.007 \mathrm{yr}^{-1}\right)$, this condition would be reached in $\sim 70$ years (based on regression equation, Figure 4 ).

[24] At site 7, were groundwater was reached by our sampling cores, the water table was at progressively greater depth from the surface as we moved from irrigated agriculture (IA, $2 \mathrm{~m})$, to OA $(3 \mathrm{~m})$ to DF $(5 \mathrm{~m})$ (Figure 2). Water content exceeded field capacity $\left(\theta_{\mathrm{r}}>1\right)$ as the capillary zone was reached in these profiles $(0.5$ and $4.5 \mathrm{~m}$ below the surface in IA and DF stand, respectively).

\subsection{Solute Distribution and Stock}

[25] In DF stands chloride concentration was highest between 1 and $4 \mathrm{~m}$ depth (Figure 5), with peaks ranging from 2.3 to $8.7 \mathrm{~g} / \mathrm{L}$ of pore water. In OA stands, no chloride peaks were found above $6 \mathrm{~m}$ depth and only the extension of a single profile down to $10 \mathrm{~m}$ revealed a peak of 1.07 $\mathrm{g} / \mathrm{L}$ of pore water down to that depth. Statistical analysis 
Volumetric water content (\% v/v)
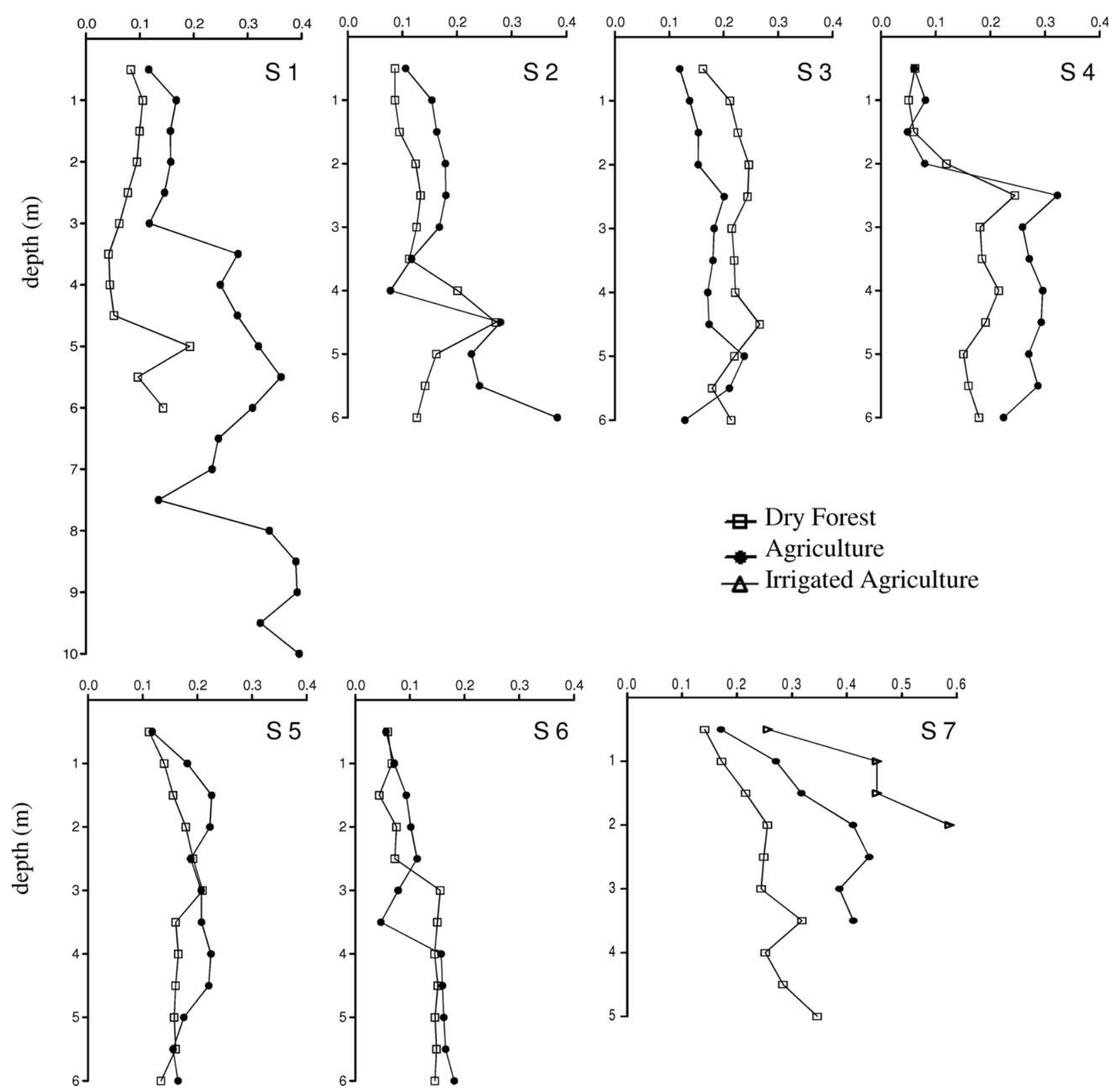

Figure 2. Volumetric water content $\left(\mathrm{m}^{3} / \mathrm{m}^{3}\right)$ along soil profiles. Sites (S) $1,2,3$, and 4 correspond to paired stands of 30 years of rain-fed agriculture and dry forests (DF). Site 6 corresponds to paired stands of 20 year rain-fed pasture and DF. Site 5 corresponds to 3 year rain-fed agriculture and DF. Site 7 corresponds to 30 year old agriculture with and without irrigation and DF.

revealed that land use interacts significantly with depth only down to $2 \mathrm{~m}$. Below that depth, land use accounted for more than $60 \%$ of the total variation of chloride concentration pore water (repeated measures ANOVA: $p$ value for land use $=0.013 ; p$ for depth $<0.0001 ; p$ for interaction $=0.0001$. Up to $2 \mathrm{~m}$ depth: $p$ for land use $=0.035$; $p$ for depth $=0.002 ; p$ for interaction $=0.0017$. Below $2 \mathrm{~m}$ depth: $p$ for land use $=0.013 ; p$ for depth $=0.25 ; p$ for interaction $=0.5$ ).

[26] The OP stand showed a similar pattern than OA stands at the first $3 \mathrm{~m}$, with a chloride accumulation peak at $3.5 \mathrm{~m}$ depth (3.7 g/L, Figure 5), yet, below that depth, the chloride profile was similar to the one observed throughout DF stands. The NA stand had an even higher chloride concentration than DF with a peak of $13.6 \mathrm{~g} / \mathrm{L}$ at $3 \mathrm{~m}$ depth. These stands, which were cleared more recently, had their chloride peaks at intermediate depth between DF and OA peaks. We found a linear decrease of chloride concentration with time since clearing and cultivation, suggesting that profiles down to $6 \mathrm{~m}$ depth would reach minimum amounts of chloride in $\sim 30$ years (based on regression equation, Figure 4).

[27] At site 7, DF showed the chloride peak (14.2 g/L) above the water table at $4 \mathrm{~m}$ depth (Figure 5). The rain-fed 
Table 2. Deep Soil Water and Chloride Accumulation and Recharge Estimates ${ }^{\mathrm{a}}$

\begin{tabular}{|c|c|c|c|c|c|c|c|}
\hline \multirow[b]{2}{*}{ Site } & \multirow[b]{2}{*}{ Use } & \multirow[b]{2}{*}{$\begin{array}{l}\text { Water Storage } \\
\quad(\mathrm{mm})\end{array}$} & \multirow[b]{2}{*}{$\begin{array}{l}\text { Chloride Storage } \\
\qquad\left(\mathrm{g} / \mathrm{m}^{2}\right)\end{array}$} & \multirow[b]{2}{*}{$\begin{array}{l}\text { Recharge mm } \mathrm{yr}^{-1} \\
\text { (CMB) }\end{array}$} & \multirow[b]{2}{*}{$(\mathrm{CFD})^{\mathrm{b}}$} & \multicolumn{2}{|c|}{ Time $(y r)^{c}$} \\
\hline & & & & & & $12 \mathrm{~m}$ & $20 \mathrm{~m}$ \\
\hline \multirow[t]{3}{*}{$1^{d}$} & $\mathrm{OA}$ & 1332 & 443 & & & & \\
\hline & $\mathrm{OA}$ & 2558 & 1638 & 1.77 & 49.82 & 38.56 & 52.64 \\
\hline & $\mathrm{DF}$ & 548 & 1163 & 0.11 & & & \\
\hline \multirow[t]{2}{*}{2} & $\mathrm{OA}$ & 1136 & 304 & 2.38 & $>27.41$ & $<74.22$ & $<97.57$ \\
\hline & DF & 834 & 11,054 & 0.03 & & & \\
\hline \multirow[t]{2}{*}{3} & OA & 1313 & 989 & 1.60 & $>33$ & $<75.35$ & $<121.41$ \\
\hline & DF & 1024 & 13,262 & 0.03 & & & \\
\hline \multirow[t]{2}{*}{4} & $\mathrm{OA}$ & 1246 & 602 & 2.01 & $>35.27$ & $<67.87$ & $<101.90$ \\
\hline & DF & 805 & 9417 & 0.07 & & & \\
\hline \multirow[t]{2}{*}{5} & NA & 1145 & 23,029 & 0.02 & 86.67 & 29.36 & 43.21 \\
\hline & DF & 962 & 10,593 & 0.03 & & & \\
\hline \multirow[t]{2}{*}{6} & OP & 692 & 3767 & 0.65 & 10.94 & 251.16 & 353.53 \\
\hline & DF & 681 & 6309 & 0.04 & & & \\
\hline
\end{tabular}

${ }^{\mathrm{a}} \mathrm{CMB}$, Chloride Mass Balance Approach; CFD, Chloride Front Displacement Approach.

${ }^{\mathrm{b}}$ Recharge estimations with CFD method in sites 1,3 , and 5 was made with the observed chloride peak in agricultural stands. In other stands a chloride peak under $6 \mathrm{~m}$ depth was assumed, so recharge estimations are subestimated and indicated with $>$ sign.

${ }^{\mathrm{c}}$ Time (years) corresponds to estimated time for water table to rise up to first meters of soil. This estimation was made assuming two different water table depths, 12 and $20 \mathrm{~m}$.

${ }^{\mathrm{d}}$ Borehole in agricultural stand was $10 \mathrm{~m}$ depth, we quantified water and chloride storage for 6 and $10 \mathrm{~m}$ depth.

and irrigated agriculture stand from this site accumulated chloride above $1.5 \mathrm{~m}$ depth, yet their concentration values were lower than in $\mathrm{DF}$, reaching 0.27 and $0.15 \mathrm{~g} / \mathrm{L}$ of pore water, respectively (Figure 5). These profiles showed a reverse pattern compared to other cultivated stands, with highest chloride concentration taking place in the first meters of the profile. Groundwater chloride concentrations at the water table were $8.91,0.23$, and $0.13 \mathrm{~g} / \mathrm{L}$ for $\mathrm{DF}$, $\mathrm{OA}$, and IA, respectively, whereas the Juramento River showed a concentration of only $0.09 \mathrm{~g} / \mathrm{L}$.

[28] Chloride stocks were, on average, 94\% lower under OA than under DF stands $\left(0.05 \pm 0.04 \mathrm{~kg} / \mathrm{m}^{2}\right.$ versus $0.77 \pm 0.4 \mathrm{~kg} / \mathrm{m}^{2} ; t$ test $\left.: p<0.0001\right)$. The coefficients of

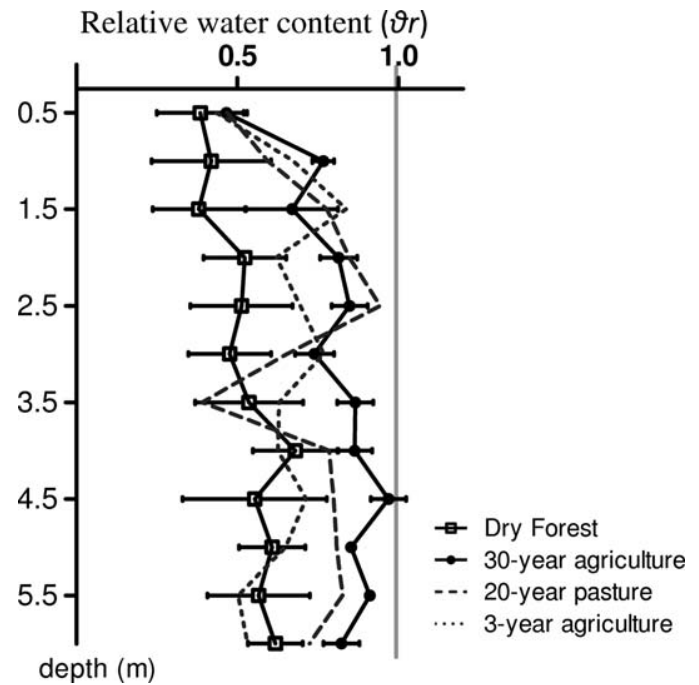

Figure 3. Relative water content $\left(\theta_{r}\right)$ of all soil profiles. This index assigns a value of 1-18 field capacity and a value of 0 to air dry soil. In the case of dry forest and 30 year old 19 agriculture stands, bars show standard deviation ( $n=6$ and 4, respectively), whereas for the 20 rest of the profiles represent single stands. variation were $52.8 \%$ for DF and $88.8 \%$ for OA. Chloride stocks for OP and NA were, on average, 0.31 and $0.97 \mathrm{~kg}$ / $\mathrm{m}^{2}$, respectively. Total salt stocks, as suggested by electric conductivity measurements $(\mathrm{EC}, \mathrm{dS} / \mathrm{m})$ were $57 \%$ lower for OA stands than for DF stands $(p<0.001)$. EC and chloride profiles differed in their vertical distribution and the location of peaks. Lower chloride increments per $\mathrm{kg} \mathrm{m}^{-2}$ of total salt, as suggested by EC measurements (supporting information Figure S2) in OA compared to DF, indicated that chloride was the first anion to become leached with the onset of deep drainage. Soil profiles had a similarly

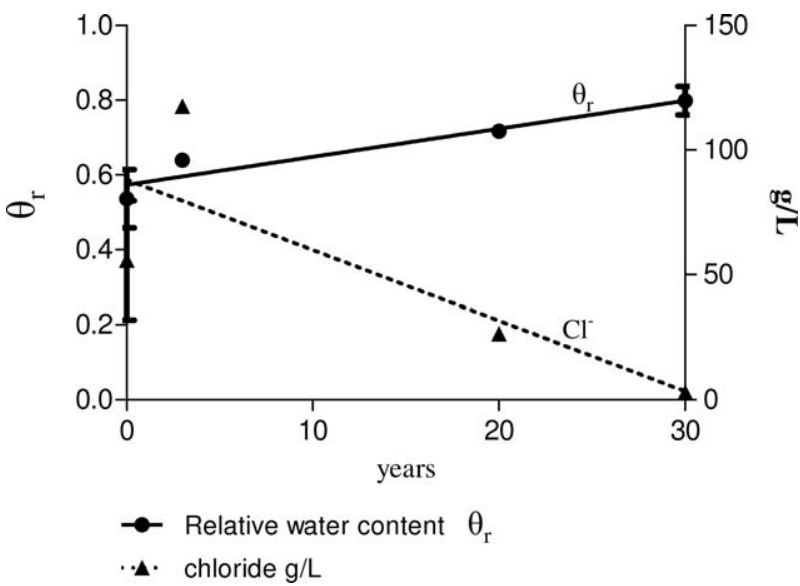

Figure 4. Relative water content $\left(\theta_{r}\right.$, left $Y$ axis $)$ and chloride concentration in the soil solution (right $Y$ axis) for different time since forest clearance. Standard deviation included in dry forest (time 0 years, no clearance; $n=6$ ) and 30 years agriculture (time 30 years; $n=4)$. The $\theta_{r}(\%)$, was obtained as the volumetric water content $\left(\theta_{v} \%\right)$ measured over the volumetric field capacity $\left(F C_{v} \%\right)$ as obtained from USDA 1992 based on texture. Fitted functions are $\theta_{r}$ $=0.007$. age of clearance $+0.5\left(R^{2}=0.9 ; p=0.044\right) . \mathrm{Cl}^{-}$ $(\mathrm{g} / \mathrm{L})=-1.99$ clearance age $+64.7 \mathrm{~g} / \mathrm{L}\left(R^{2}=0.57 ; p=\right.$ $0.0043)$. 

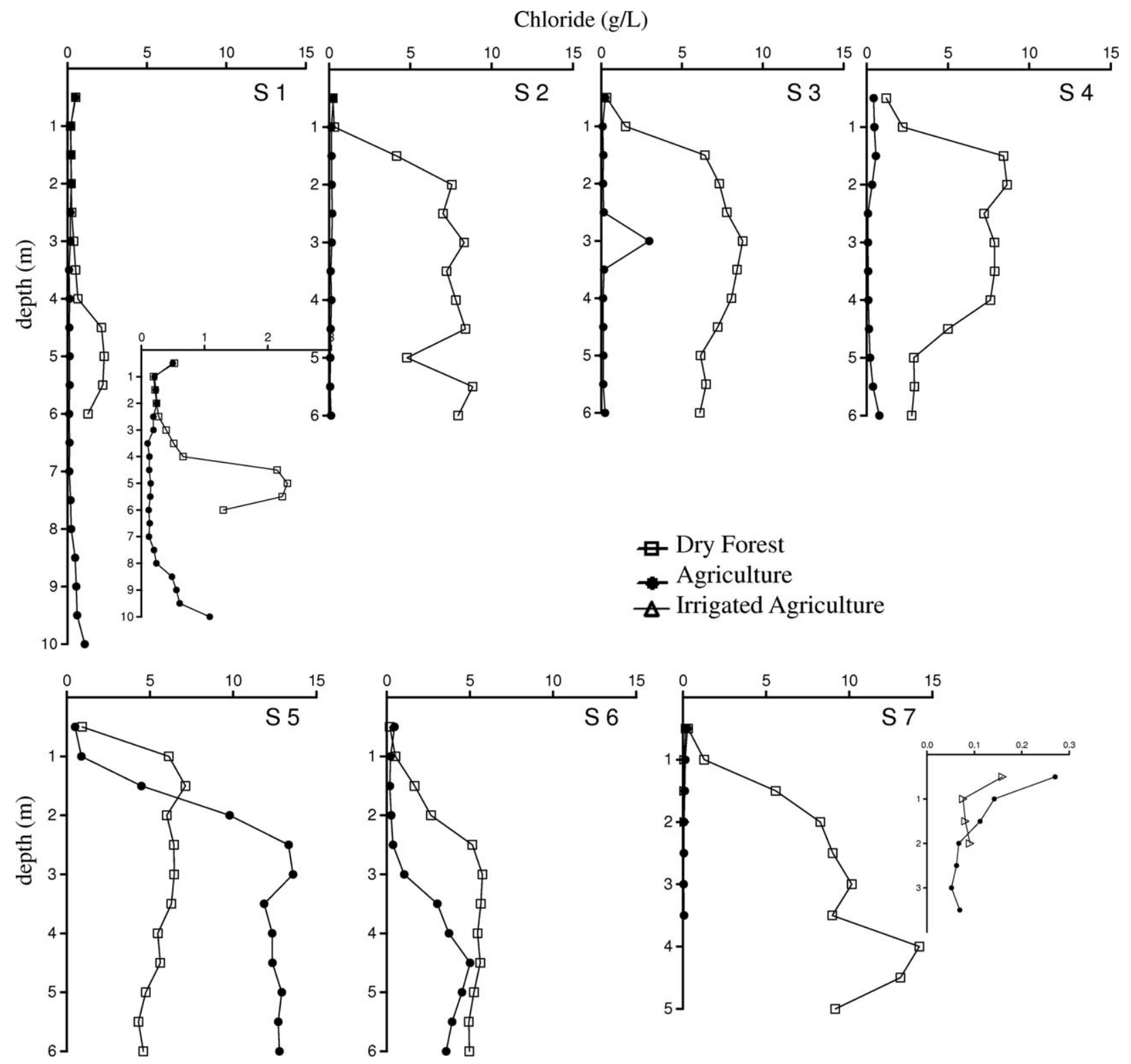

Figure 5. Distribution of chloride concentration (g/L of soil solution) in the soil profiles. Sites ( $\mathrm{S}) 1,2$, 3 , and 4 correspond to rain-fed agriculture stands of 30 years age. Site 6 corresponds to paired stands of 20 year rain-fed pasture and DF. Site 5 corresponds to 3 year rain-fed agriculture and DF. Site 7 corresponds to 30 year old agriculture with and without irrigation and DF. Insets show the same data using detailed scales. Insets show the same data using detailed scale.

alkaline reaction in agricultural stands and DF $(\mathrm{pH}$ $8.01 \pm 0.6$, repeated measures ANOVA $p>0$ ).

\subsection{Recharge Estimates}

[29] Recharge estimates based on the chloride mass balance approach (CMB) showed an order of magnitude difference between dry forest stands $\left(<0.1 \mathrm{~mm} \mathrm{yr}^{-1}\right)$ and old agriculture $\left(>1 \mathrm{~mm} \mathrm{yr}^{-1}\right)$ (Table 2$)$. OA cumulative chloride $\left(\mathrm{g} / \mathrm{m}^{2}\right)$ versus cumulative water $\left(\mathrm{mm}=\mathrm{L} / \mathrm{m}^{2}\right)$ curves had increasing slopes $(>0$ and $<1 \mathrm{~g} / \mathrm{L})$ below 2 and $3 \mathrm{~m}$ depth. DF slopes increase under $1.5 \mathrm{~m}$ and were higher than those found in agriculture $(>0$ and $<10 \mathrm{~g} / \mathrm{L})$. These results suggest higher enrichment of the soil solution due to more intense evapotranspirative consumption throughout the profile in DF. At OP and NA stands lower recharge contrasts with their forest pairs were found (Table 2).

[30] Recharge values under deforested stands calculated using the chloride front displacement method (CFD) were significantly higher than those obtained with the CMB approach. As no chloride peaks where found in most old agricultures down to $6 \mathrm{~m}$ depth, results indicate a minimum boundary value of deep drainage as chloride peaks had already reached greater depths than those explored in this study (Table 2). Old agriculture deep drainage estimates were 27.4 to $>49.8 \mathrm{~mm} \mathrm{yr}^{-1}$. New agriculture and the old pasture recharge values were 86.7 and $10.9 \mathrm{~mm} \mathrm{yr}^{-1}$, respectively, in accordance with $\mathrm{CMB}$ method results. The CFD method estimates and moisture profile data were used to calculate tentative times for groundwater reaching the 
surface (see assumptions in section 2). Starting with a water table at 12 or $20 \mathrm{~m}$ of depth, assuming no later groundwater flow, the surface could be reached in a periods ranging 38 75 and 52-121 years for each time interval, respectively. It is important to highlight that water table rising rates could be higher at present times as recharge rates (as estimated with CFD) showed larger values for NA than OA (86 mm $\mathrm{yr}^{-1}$, Table 2). The number of years since clearance (3 years) and the very low sand content in the profile (Table 1) could explain the behavior of that stand. For the OP stand water table could reach the surface between 251 and 353 years depending on its original depth (12 and $20 \mathrm{~m}$ depth, respectively) (Table 2).

\section{Discussion}

[31] Land-use conversions from natural semiarid woody ecosystems to agriculture in the east of Salta resulted in significant increases in soil profile moisture contents and decreases in salt content providing evidence for the onset of deep drainage and salt leaching following deforestation and cultivation. Water and solute storage and vertical distribution showed an expected variation between land covers and with time after clearance. Dry forest had lower water contents and high chloride storage through the soil profiles evidencing very low deep recharge fluxes. Agriculture introduced a clear change in chloride and water vertical patterns and three decades after its establishment chloride peaks migrated down to $6 \mathrm{~m}$ depth or more and moisture contents approached field capacity. A draining surplus of about $30-60 \mathrm{~mm} \mathrm{yr}^{-1}$ is necessary to explain such differences (Figure 3) in concordance with estimates of groundwater recharge for cleared stands (CFD method, 27-50 mm $\left.\mathrm{yr}^{-1}\right)$. In addition, the position of chloride peaks could indicate a progressive mobilization of salts along the clearance chronosequence. Even though the fitted line of the chronosequence (Figure 4) presents uncertainty because of the few measured temporal points, is an attempt to assess the potential water table recharge as it is the most critical issue in these systems at land use changes. To reinforce these results, we took into account that in spite of the initial variability in chloride stocks in dry forests $\left(0.37-1.17 \mathrm{~kg} / \mathrm{m}^{2}\right)$, agricultural stands converged to similarly low chloride concentration values $\left(<0.54 \mathrm{~kg} / \mathrm{m}^{2}\right)$, suggesting that the leaching process throughout the first $6 \mathrm{~m}$ of the profiles was independent of the initial salt concentration. Following these observations water table under rain-fed agriculture may reach soil surface in a period that ranges $\sim 30$ to $\sim 120$ years. Such observations are consistent with the ecohydrological transformations triggered by analog land use changes evaluated in similar systems in Australia [George et al., 1997], the semiarid plains of the Sahel [Scanlon et al., 2006] and the province of San Luis in Argentina [Santoni et al., 2010; Contreras et al., 2012; Jayawickreme et al., 2011]. Discrepancies between CFD and CMB methods for recharge estimate are also consistent with previous evaluations (Table 2). CMB results for the agricultural stands analyzed in this study were one or two orders of magnitude lower than those obtained in other similar regions with the same kind of land conversion [Scanlon et al., 2009; Jayawickreme et al., 2011]. Gee et al. [2005] revised $\mathrm{CMB}$ method concluding that it is useful for esti- mates of few millimeters per year, over a minimum recharge value this method can lead to unreliable estimates of recharge. An overview to preferential flows suggest there are remaining areas of the soil matrix which are not completely drained, as a result peaks shifts and moisture increases occur simultaneously but chloride pockets remain keeping original ion concentration [Amiaz et al., 2011]. In other words, pore water does not necessarily match drainage water and $\mathrm{CMB}$ method is based on the relationship between $\mathrm{Cl}^{-}$depositions and $\mathrm{Cl}^{-}$soil concentrations. Furthermore, the particular setting of one of our study sites in which water table was closer to the surface (site 7) provided a possible example of future states of the process of groundwater recharge according with CFD method results. Even though these stands were very close to an artificial drainage channel, vegetation effect on water table depths was still present. Dry forest had the deepest water table at 5 $\mathrm{m}$ depth and the rain-fed and irrigated agricultural situations had it at 3.5 and $2 \mathrm{~m}$ of depth, respectively. The proximity of the water table to the surface could explain why agricultural stands in this site have higher rather than lower salt content in their profiles compared to the dry forest.

[32] Water accumulation and drainage can be explained by the evapotranspiration shifts that accompanied land use conversions [Nosetto et al., 2007; Jobbágy et al., 2008]. The studied sites represent the agriculture system in NW Argentina which is mostly based on no-tillage management followed by fallow seasons [INTA, 2005]. The crop residue associated to no-tillage systems decreases soil evaporation [Salado-Navarro et al., 2013] and therefore increases available soil water. During fallow season, there is no consumption of soil water, generating a more positive water balance and hence deep drainage. The old pasture, for example, showed 4-8 times lower recharge rates than croplands (Table 2). Pastures are dominated by perennial C4 grasses species (mainly Panicum maximum) which have deeper roots than annual rain-fed crops [Schenk and Jackson, 2005] and consume water right after the onset of rains and sustain consumption for longer periods than crops. We can expect that perennial pastures and deep root crops like safflower (Carthamustinctorius L.) could reduce the effects of forest clearing on deep drainage and ground water recharge, as root length and perennial systems are one of the most important attributes determining water consumption in arid and semi arid conditions [Noy Meir, 1973].

[33] In the Gran Chaco of South America dry forests are converted to agriculture at some of the highest rates observed in the world [Volante et al., 2011]. The most common agricultural systems (soybean monoculture and double cropping wheat-soybean) have no more than 30 years and their ecohydrological consequences had not been thoroughly assessed. In Australia, more than a century of dryland agriculture over deforested territories offered a painful lesson on how lagged ecohydrological impacts can emerge when a very large fractions of the landscapes are under agricultural use, causing in that country the loss of $60,000 \mathrm{~km}^{2}$ of agricultural land [George et al., 1997; NLWRA, 2001; Jobbágy et al., 2008]. In semiarid plains of Sahel, Africa, the establishment of rain-fed crops replacing natural vegetation generated an increment of one order of magnitude in the recharge rate [Scanlon et al., 2006]. In San Luis province of Argentina, land conversion increased 
recharge rate also in two orders of magnitude [Santoni et al., 2010]. The empirical observations of the groundwater level rise in other sites are in the range of time we estimated for Salta [Scanlon et al., 2009; Jayawickreme et al., 2011], but structural and geochemical discrepancies between the cited regions could lead to different intensities and magnitudes of the salinization process. Two aspects suggest that the problem can be less intense in the Chaco but a third one suggest the opposite. In the first place, in Australia and the Sahel [Edmunds and Gaye, 1994; George at al., 1997] natural soil salt stocks seem to be higher than in the Gran Chaco [supporting information Figure S2; Santoni et al., 2010; Jayawickreme et al., 2011] what may result in a less intense deterioration. In addition, evapotranspiration in agricultural plots, as inferred with remote sensing tools, is higher in the Gran Chaco than climatically similar regions in Australia or Africa [Jobbágy et al., 2008; Baldi et al., 2013] suggesting that those regions are subject to higher recharge rates following deforestation. Yet a third aspect to consider is the extremely flat topography of the Gran Chaco [Jobbágy et al., 2008], which can favor the expansion of waterlogging and flooding over a large proportion of the landscape as it currently does in the neighboring Pampas region [Aragón et al., 2010].

[34] A more accurate and detailed estimate of the dynamics of solutes present in the profile would be require to improve the available information. Interestingly, the correlation between total solute and chloride concentration was higher for dry forest than for agricultural stands (supporting information Figure S2), highlighting that (i) other anions, may be very abundant in these soils and (ii) that they may leach at slower rates then chloride suggesting that total salt transport to the water table could take more time than that estimated for chloride. The composition of solutes present in the profile, play a crucial role over the effects on soil structure in case of a rising water table. For example, salt compositions with high residual sodium carbonate $\left(\mathrm{Ca}^{2+}+\mathrm{Mg}^{-}<\mathrm{HCO}_{3}+\mathrm{CO}_{3}\right)$ have a more damaging effect on soils as they not only pose an osmotic limitation to plant growth but also become highly dispersive deteriorating soil structure. Minority components like arsenic and fluorine, abundant in the sedimentary material and groundwater of Southern South America [Osicka et al., 2002; Cabrera et al., 2001] can create toxicity problems even before total salt concentrations have a deleterious effect on plants and animals.

[35] The assessment of the impacts of deforestation in the Gran Chaco should also have a landscape perspective, as the location, context, timing, extent, and type of land use replacement would have an effect on the groundwater recharge that cannot be estimated by plot scale analyses. The length of borders and the fragmentation level would play a critical role in defining the landscape water balance [Briant et al., 2010] and hence the magnitude of the recharge. To what extend forest patches can absorb the water drained from nearby agricultural patches? Are there landscape configurations that, given a ratio of forests/croplands, minimize groundwater recharge? What land use alternatives could minimize or reverse the recharge process? To address this issue, a spatial explicit quantification of evapotranspiration, using remote sensing tools [Nosetto et al., 2005], would allow us to relate water balance with landscape configuration including different land covers types and their consume of water.

[36] Our results indicate that replacement of native vegetation for rain-fed agriculture is a critical control of the long-term water and salt transport. More over annual agriculture seems to be one of the most risky options for the semiarid Chaco system. The consequences of these processes could affect the level of provision of regulation ecosystem services and eventually threaten the regeneration of the forest. Moreover, in a period of decades it would greatly affect the sustainability of the agricultural production. Land use planning should include, in addition to the regulation of land clearing, development of land use alternatives that minimize or reverse the consequences of dryland farming on the dynamics of water and salts. The use of perennial crops, silvopastoral systems, irrigation using local groundwater, and forestry for energy production are some options to evaluate and experiment.

[37] Acknowledgments. We thank the very helpful field and laboratory collaboration provided by Silvina Ballesteros, Ricardo Paez, Marcelo Nossetto, María Vallejos, Lucía Ciuffoli, Cristian Campos, Santiago Verón, Lucas Seghezzo, Federico Mónico (INTA, Agencia de Extensión Rural de JV Gonzalez), Raissa Huyckman, Dolores Arocena and Marisa Puente. Special thanks to the Grupo de Estudios Ambientales (GEA), the Laboratorio de Análisis Regional y Teledetección (LART), and the Laboratorio de Teledetección y SIG INTA, Salta for their contributions and support. Special mention to teacher Antonio Quintana from Escuela 4766 de Pje. Los Pozos, Salta. This work was funded by grants from Fondo Nacional de Ciencia y Técnica (FONCYT-PICT 2199), Universidad de Buenos Aires (UBACYT G006), the International Research Development Center (IDRC-Canada, project 106601-001), and the Inter-American Institute for Global Change Research (IAI-CRN II 2031 and CRNII 3095) which is supported by the U.S. National Science Foundation (grant GEO-0452325), and the U.S. National Science Foundation (BIO-0717191).

\section{References}

Allison, G. B., W. J. Stone, and M. W. Hughes (1985), Recharge in karst and dune elements of a semi-arid landscape as indicated by natural isotopes and chloride, J. Hydrol., 76, 1-25.

Allison, G. B., G. W. Gee, and S. W. Tyler (1994), Vadose-zone techniques for estimating groundwater recharge in arid and semiarid regions, Soil Sci. Soc. Am. J., 58, 6-14.

Aragón, R., E. G. Jobbágy, and E. F. Viglizzo (2010), Surface and groundwater dynamics in the sedimentary plains of the Western Pampas (Argentina), Ecohydrology, 4, 433-447.

Baldi, G., S. R. Verón, and E. G. Jobbágy (2013), The imprint of humans on landscape patterns and vegetation functioning in the dry subtropic, Global Change Biol., 19, 441-458.

Bianchi, A. R., C. E. Yáñez, and L. R. Acuña (2005), Base de datos mensuales de precipitaciones del Noroeste Argentino, 41 pp., Inst. Nac. de tecnología Agropecuaria, Proyecto Riesgo Agropecuario, Convenio Específico, 3 al Convenio 141 INTA-SAGPYA.

Bouyoucos, G. J. (1962), Hydrometer method improved for making particle size analysis of soils, Agron. J., 54, 464-465.

Briant, G., V. Gond, and S. G. W. Laurance (2010), Habitat fragmentation and the desiccation of forest canopies: A case study from eastern Amazonia, Biol. Conserv., 143(11), 2763-2769.

Brown, A., U. Martínez Ortíz, M. Acerbi, and J. Corcuera (Eds.) (2006), La situación Ambiental Argentina 2005, 587 pp., Fundación Vida Silvestre Argent., Buenos Aires.

Cabrera, A., and M. Blarasin (2001), Geoquímica de Flúor y Arsénico en el agua subterránea del sur de Córdoba, Argentina, in Las caras del agua subterránea: Congreso, en memoria de Germán Alfonso Galarza López, pp. 17-26, Inst. Geol. y Minero de España.

Cabrera, A. L. (1976), Regiones fitogeográficas de la República Argentina, in Enciclopedia de Agricultura, Jardinería y Fruticultura, vol. 2, 2nd ed., pp. 1-85, ACME S.A. C. I., Buenos Aires, Argentina.

Contreras, S., C. S. Santoni, and E. G. Jobbágy (2012), Abrupt watercourse formation in a semiarid sedimentary landscape of central Argentina: The 
roles of forest clearing, rainfall variability and seismic activity, Ecohydrology, 6, 794-805, doi:10.1002/eco.1302.

Cook, P. G., G. R. Walker, and I. D. Jolly (1989), Spatial variability of groundwater recharge in a semiarid region, J. Hydrol., 111, 195-212, doi:10.1016/0022-1694(89)90260-6.

Daniel, P., and L. Marbán (1989), Adaptación de un método espectrofotométrico reductivo para la determinación de nitratos, Boletín de la AACS, 58, 3-8.

Del Castillo Zapater de, M. A. (1985), Esquema Fitogeográfico de la Provincia de Salta, Secretaria de Estado de Asuntos Agrarios, Dir. Gen. Agropecuaria, Dep. Suelo, Riego y Clima, Salta, Argentina.

Edmunds, W. M., and C. B. Gaye (1994), Estimating spatial variability of groundwater recharge in the Sahel using chloride, J. Hydrol., 156, 4759, doi:10.1016/0022-1694(94)90070-1

Elliot, E. T., J. W. Jeil, E. F. Kelly, and H. Curtis Monger (1999), Soil structural and other physical properties, in Standard Sail Methods for Long Term Ecological Research, edited by G. P. Robertson et al., pp. 74-85, Oxford Univ. Press, New York.

FAO (Food and Agriculture Organization of the United Nations) (2009), State of the World's Forests 2009, 168 pp., Rome.

Feinsinger, P. E., E. Spears, and R. W. Poole (1981), A simple measure of niche breadth, Ecology, 62(1), 27-32.

Frankenberger, W. T., M. A. Tabaitabai, D. C. Adriano, and H. E. Doner (1996), Bromine, chlorine and fluorine, in Methods of Sail Analysis Part 3, edited by S. L. Sparks, pp. 833-868, Am. Soc. of Agron., Madison.

Fuertes, A. (2004), Programa marco para la gestión sostenible de los recursos hídricos de la cuenca del Plata en relación con los efectos hidrogeológicos de la variabilidad y el cambio climático, Caso de estudio sistema acuífero Yrenda-Toba-Tarijeño Paraguay-Argentina-Bolivia, UNESCO/OEA/ISARM/AMERICAS, INASLA.

García, R. F. (1998), Hidrogeología del Chaco Boreal Salteño, Tesis Doctoral, Fac. de Cienc. Nat., Univ. Nac. de Salta, Salta, Argentina.

Gee, G. W., Z. F. Zhang, S. W. Tyler, W. H., Albright, and M. J. Singleton (2005), Chloride mass balance, Vadose Zone J., 4(1), 72-78.

George, R. J., D. J. McFarlane, and N. A. Nulsen (1997), Salinity threatens the viability of agriculture and ecosystems in Western Australia, Hydrogeol. J., 5, 6-21.

Grau, R. H., I. Gasparri, and M. Aide (2008), Balancing food production and nature conservation in the Neotropical dry forests of northern Argentina, Global Change Biol., 14, 985-997.

INTA (Instituto Nacional de Tecnología Agropecuaria) (2009a), Desarrollo metodológico y operativo para el relevamiento, correlación y evaluación de tierras, Área piloto: Las Lajitas, provincia de Salta, Ediciones INTA 2009. [Available at http://www.inta.gov.ar/prorenoa/info/suelos_lajitas. $\mathrm{htm}$, Accessed 10 December 2012.]

INTA (Instituto Nacional de Tecnología Agropecuaria) (2009b), Carta de suelos 2009. [Available at http://geointa.inta.gov.ar/publico/INTA SUELOS/, Accessed 23 December 2012.].

Iriondo, M. (1993), Geomorphology and late quaternary of the Chaco (South America), Geomorphology, 7, 289-303.

Leblanc, M. J., G. Favreau, S. Massuel, S. O. Tweed, and M. Loireau (2008), Land clearance and hydrological change in the Sahel: SW Niger, Global Planet. Change, 61(3-4), 135-150.

Leduc, C., G. Favreau, and P. Schroeter (2001), Long-term rise in a Sahelian water-table: The continental terminal in South-West Niger, $J$. Hydrol., 243, 43-54.

Jayawickreme, D. H., C. S. Santoni, J. H. Kim, E. G. Jobbágy, and R. B. Jackson (2011), Changes in hydrology and salinity accompanying a century of agricultural conversion in Argentina, Ecol. Appl., 21(7), 23672379.

Jobbágy, E. G., and R. B. Jackson (2003), Patterns and mechanisms of soil acidification in the conversion of grasslands to forests, Biogeochemistry, 64, 205-229.

Jobbágy, E. G., and R. B. Jackson (2004), Groundwater use and salinization with grassland afforestation, Global Change Biol., 10, 1299-1312.

Jobbágy, E. G., M. D. Nosetto, C. S. Santoni, and G. Baldi (2008), El desafío ecohidrológico de las transiciones entre sistemas leñosos y herbáceos en la llanura Chaco-Pampeana, Ecol. Aust., 18, 305-322.

Nitsch, M. (1995), El desmonte en el chaco central del Paraguay: Influencia sobre el agua subterránea y la salinización de los suelos, Trabajo presentado en el $2^{\circ}$ Simposio Sobre Aguas Subterráneas y Perforación de Pozos en el Paraguay, Dep. de Abastecimiento de Agua para el Chaco_Paraguay, San Lorenzo, Paraguay.
Nitsch, M., R. Hoffmann, J. Utermann, and L. Portillo (1998), Soil salinization in the central Chaco of Paraguay: A consequence of logging, $A d v$. Geoecol., 3, 495-502.

NLWRA (National Land and Water Resources Audit) (2001), National Land and Water Resources Audit Australian Dryland Salinity Assessment 2000: Extent, Impacts, Processes, Monitoring and Management Options, 771 pp., Natural Heritage Trust, Canberra, Australia.

Nolan, B. T., R. W. Healy, P. E. Taber, K. Perkins, K. J. Hitt, and D. M. Wolock (2007), Factors influencing ground-water recharge in the eastern United States, J. Hydrol., 332, 187-205.

Nosetto, M. D., E. G. Jobbágy, and J. M. Paruelo (2005), Land use change and water losses: The case of grassland afforestation across a soil textural gradient in Central Argentina, Global Change Biol., 11, 11011117.

Nosetto, M. D., E. G. Jobbágy, T. Toth, and C. M. Di Bella (2007), The effects of tree establishment on water and salts dynamics in naturally salt-affected grasslands, Oecologia, 152, 695-705.

Noy-Meir, I. (1973), Desert ecosystems: Environment and producers, Ann. Rev. Ecol. Syst., 4, 25-32.

Osicka, R. M., N. S. Agulló, C. E. Herrera Aguad, and M. C. Giménez (2002), Evaluación de las concentraciones de fluoruro y arsénico en las aguas subterráneas del Domo Central de la Provincia del Chaco. [Available at www.msal.gov.ar/htm/site/pdf/FyAsChaco.pdf, Accessed 3 March 2013.]

Paruelo, J. M., E. G. Jobbágy, and O. E. Sala (2001), Current distribution of ecosystem functional types in temperate South America, Ecosystems, 4, 683-698.

Paruelo, J. M., et al. (2011), Elementos conceptuales y metodológicos para la Evaluación de Impactos Ambientales Acumulativos (EIAAc) en bosques subtropicales, El caso del Este de Salta, Argentina, Ecol. Aust., 21(2), 163-178.

Pavelic, P., P. J. Dillon, K. A. Narayan, T. N. Herrmann, and S. R. Barnett (1997), Integrated groundwater flow and agronomic modelling for management of dryland salinity of a coastal plain in southern Australia, Agric. Water Manage., 35, 75-93.

Phillips, F. M. (1994), Environmental tracers for water movement in desert soils of the American Southwest, Soil Sci. Soc. Am. J., 58, 15-24.

Rawls, W. J., L. R. Ahuja, and D. L. Brakensiek (1992), Estimating soil hydraulic properties from soils data, in Proceedings of International Workshop on Indirect Methods for Estimating the Hydraulic Properties of Unsaturated Soils, edited by M. Th. van Genuchten, M. Th., F. J. Leij, and L. J. Lund, pp. 329-340, Univ. of Calif., Riverside.

Ruiz, J. M. (2003), Utilización del balance de cloruros en la zona no saturada en la estimación de la recarga natural a un acuífero detrítico, Estud. de la Zona No Saturada del Suelo J., VI.

Salado-Navarro, L. R., T. R. Sinclair, and M. Morandini (2013), Estimation of soil evaporation during fallow seasons to assess water balances for notillage crop rotations, J. Agron. Crop Sci., 199(1), 57-65.

Santoni, C. S., E. G. Jobbágy, and S. Contreras (2010), Vadose zone transport in dry forest of central Argentina: Role of land use, Water Resour. Res., 46, W10541, doi:10.1029/2009WR008784.

Sayago, J. M. (1995), The Argentine neotropical loess: An overview, Quat. Sci. Rev., 14, 755-766.

Scanlon, B. R., R. W. Healy, and P. G. Cook (2002), Choosing appropriate techniques for quantifying groundwater recharge, Hydrogeol. J., 10(1), $18-39$.

Scanlon, B. R., D. G. Levitt, R. C. Reedy, K. E. Keese, and M. J. Sully (2005a), Ecological controls on water-cycle response to climate variability in deserts, PNAS, 102(17), 6033-6038.

Scanlon, B. R., R. C. Reedy, D. A. Stonestrom, D. E. Prudic, K. F. Dennehy (2005b), Impact of land use and land cover change on groundwater recharge and quality in the southwestern US, Global Change Biol., 11, $1577-1593$.

Scanlon, B. R., K. E. Keese, A. L. Flint, L. E. Flint, C. B. Gaye, W. M. Edmunds, and I. Simmers (2006), Global synthesis of groundwater recharge in semiarid and arid regions, Hydrol. Processes, 20, 33353370, doi:10.1002/hyp. 6335 .

Scanlon, B. R., D. A. Stonestrom, R. C. Reedy, F. W. Leaney, J. Gates, and R. G. Cresswell (2009), Inventories and mobilization of unsaturated zone sulfate, fluoride, and chloride related to land use change in semiarid regions, southwestern United States and Australia, Water Resour. Res., 45, W00A18, doi:10.1029/2008WR006963.

Schofield, R., D. S. G. Thomas, and M. J. Kirby (2001), Causal processes of soil salinization in Tunisia, Spain and Hungary, Land Degrad. Dev., 12, 163-181. 


\section{AMDAN ET AL.: ONSET OF DEEP DRAINAGE AND SALT MOBILIZATION}

Schenk, H. J., and R. B. Jackson (2005), Mapping the global distribution of deep roots in relation to climate and soil characteristics, Geoderma, $126(1-2), 129-140$

Thomas, G. W. (1996), Soil acidity and soil pH, in Methods of Soil Analysis-Part 3 Chemical Methods, edited by S. L. Sparks, et al., pp. 475 490, Soil Sci. Soc. Am., Madison, Wis.

Tortorelli, L. A. (2009), Maderas y bosques argentinos, 2nd ed., Orientación Gráfica Editora.

UMSEF (Unidad de Manejo del Sistema de Evaluación Forestal) (2007), Informe sobre deforestación en Argentina. Dirección de Bosques, 10 pp., Secretaría de Ambiente y Desarrollo Sustentable. [Available at http:// www.ambiente. gov.ar/archivos/web/UMSEF/, Accessed 3 March 2013.]

USDA Soil Taxonomy (United States Department of Agriculture) (1992), Soil Conservation Service, Soil Survey Staff (draft), 1983, 1972, Natl. Soils Handb., Washington, D. C.

Vargas, R. (1977), Soluciones al Problema del agua en la expansión de la frontera agropecuaria de la Provincia del Chaco - Campaña del Oeste-
Programa III-Estudio Hidrogeológico Pico del Chaco, Resistencia, Chaco, Argentina.

Volante, J. N., J. M. Paruelo, M. C. Morales Poclava, and L. Vale (2009), Dinámica espacial y temporal de la deforestación en la región Chaqueña del Noroeste Argentino en el período 1977-2007, XIII CongresoForestal Mundial 2009

Volante, J. N., D. Alcaraz-Segura, M. J. Mosciaro, E. F. Viglizzo, and J. M. Paruelo (2011), Ecosystem functional changes associated with land clearing in NW Argentina, Agric. Ecosyst. Environ., doi:10.1016/ j.agee.2011.08.012.

Walker, G. R. (1998), Using soil water tracers to estimate recharge, in Part 7 of the Basics of Recharge and Discharge, edited by L. Zhang and G. Walker, 28 pp., CSIRO, Australia.

Walker, G. R., I. D. Jolly, and P. G. Cook (1991), A new chloride leaching approach to the estimation of diffuse recharge following a change in land use, J. Hydrol., 128, 49-67. 